\title{
Gasterophilus (Diptera, Gasterophilidae) infestation of equids in the Kalamaili Nature Reserve, China
}

\author{
Heqing Huang ${ }^{1}$, Boru Zhang ${ }^{1}$, Hongjun $\mathrm{Chu}^{2}$, Dong Zhang ${ }^{1}$, and $\mathrm{Kai}^{\mathrm{Li}^{1}{ }^{1 *}}$ \\ ${ }^{1}$ Key Laboratory of Non-Invasive Research Technology for Endangered Species, College of Nature Conservation, \\ Beijing Forestry University, Beijing 100083, PR China \\ 2 Wildlife Conservation Office of Altay Prefecture, Altay 836599 Xinjiang, PR China
}

Received 18 June 2016, Accepted 16 August 2016, Published online 5 September 2016

\begin{abstract}
We investigated infections with Gasterophilus spp. in three equids within the Kalamaili Nature Reserve (northern China). We conducted necropsies on 6 Przewalski's horses (Equus ferus przewalskii) and 6 Mongolian wild asses (Equus hemionus) and administered ivermectin to 10 overwintering domestic horses to expel parasites during winter periods. All 22 equids studied (100\%) were infested with Gasterophilus spp. and a total of 17,225 larvae were collected. These included six species: G. haemorrhoidalis, G. inermis, G. intestinalis, G. nasalis, G. nigricornis, and G. pecorum. The mean intensity of Gasterophilus spp. larvae was 1904 in Przewalski's horses, 780 in Mongolian wild asses, and 113 in domestic horses. Gasterophilus pecorum was the most abundant species in all three equids. Przewalski's horses, a reintroduced species, had a significantly higher intensity of Gasterophilus spp. than the Mongolian wild ass, indicating greater susceptibility to parasites in its ancestral home.
\end{abstract}

Key words: Gasterophilus, Equids, Przewalski’s horses, Epidemiology, Differential analysis.

Résumé - Infestation des équidés par Gasterophilus (Diptera, Gasterophilidae) dans la réserve naturelle de Kalamaili, Chine. Nous avons étudié les infections de Gasterophilus spp. chez trois équidés dans la réserve naturelle de Kalamaili (Chine du Nord). Nous avons effectué des autopsies sur 6 chevaux de Przewalski (Equus ferus przewalskii) et 6 ânes sauvages de Mongolie (Equus hemionus) et administré de l'ivermectine à 10 chevaux domestiques hivernants pour expulser leurs parasites pendant les périodes d'hiver. Tous les 22 équidés étudiés (100\%) étaient infestés par Gasterophilus spp. et un total de 17,225 larves ont été recueillies. Elles comprenaient six espèces : G. haemorrhoidalis, G. inermis, G. intestinalis, G. nasalis, G. nigricornis et G. pecorum. L'intensité moyenne des larves de Gasterophilus spp. était 1904 chez les chevaux de Przewalski, 780 chez les ânes sauvages de Mongolie et 113 chez les chevaux domestiques. Gasterophilus pecorum était l'espèce la plus abondante chez les trois équidés. Les chevaux de Przewalski, une espèce réintroduite, avait une intensité significativement plus élevée de Gasterophilus spp. que les ânes sauvages de Mongolie, ce qui indique une plus grande sensibilité aux parasites dans leur aire ancestrale.

\section{Introduction}

The Kalamaili Nature Reserve (KNR) (latitude: $44^{\circ} 36^{\prime}-$ $46^{\circ} 00^{\prime} \mathrm{N}$, longitude: $88^{\circ} 30^{\prime}-90^{\circ} 03^{\prime} \mathrm{E}$, altitude: $600-1464 \mathrm{~m}$ ) is located in the desert steppe of Xinjiang, China. Nomadic Kazakh populations in KNR traditionally migrate $200 \mathrm{~km}$ northward to summer pastures every spring and return in autumn [20]. Three equid species live in the KNR: the Przewalski's horse, the Mongolian wild ass, and the overwintering domestic horse [3].

More than 150 species of internal parasites infect horses [5]. Gasterophilus spp. are obligate parasites that infest the gastrointestinal tracts of equids, affecting the horses' health

\footnotetext{
*Corresponding author: likai_sino@sina.com
}

by absorbing nutrients and secreting toxins [15, 19]. They may cause host death when the infestation is severe [4]. Gasterophilus spp. consists of nine species distributed worldwide [21]. In China, six of them are present, namely G. haemorrhoidalis, G. inermis, G. intestinalis, G. nasalis, G. nigricornis, and G. pecorum [6, 18]. All of them have been reported in wild populations of Przewalski's horses in KNR, China [9].

The present study was carried out on Przewalski's horses and Mongolian wild asses that died accidentally and with preserved corpses and feces of domestic horses following antiparasitic treatment during the winter. The aim of the study was to investigate the epidemiological features of Gasterophilus spp. in the three equid species. 


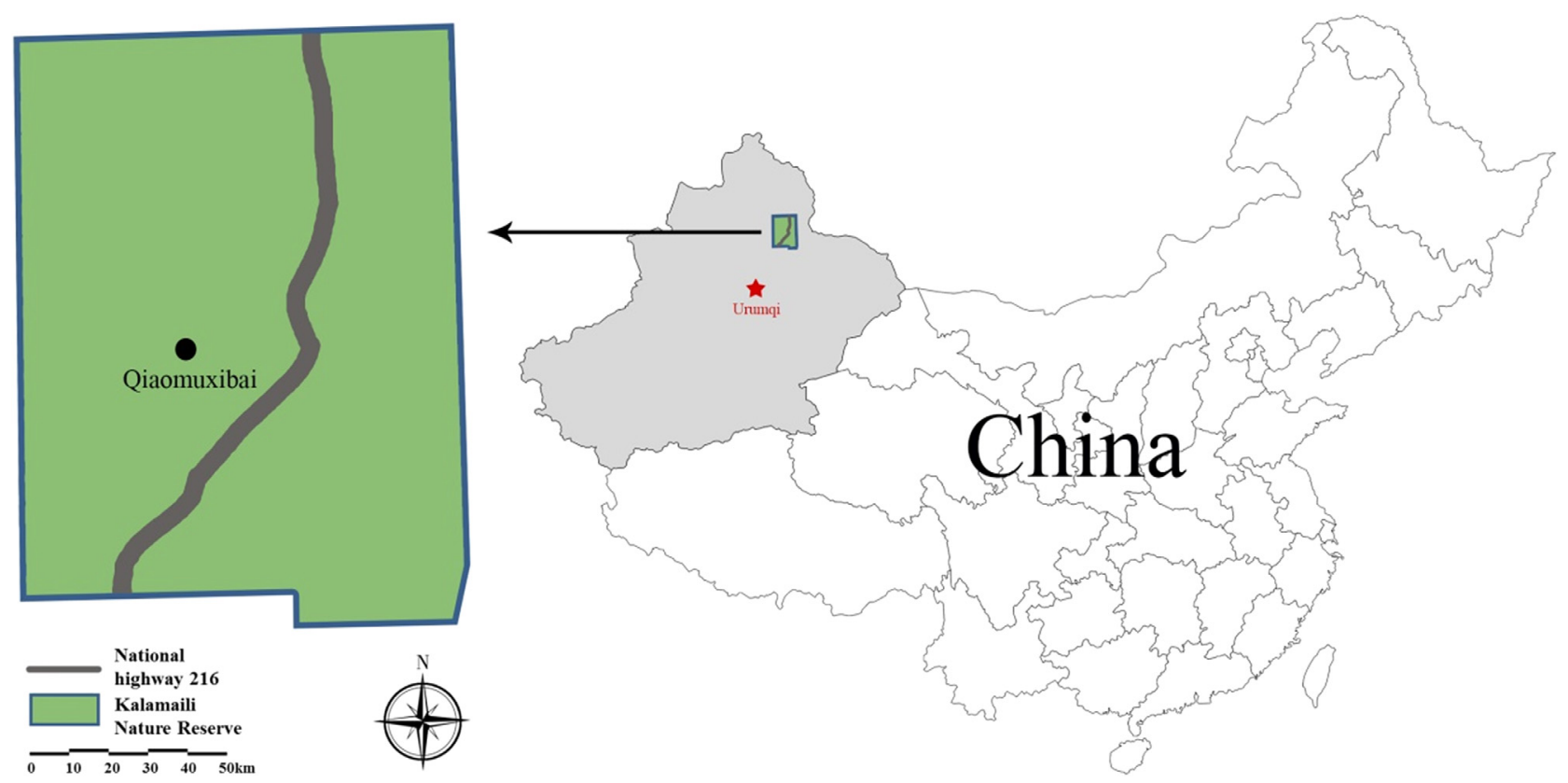

Figure 1. Location of the Kalamaili Nature Reserve, China.

\section{Materials and methods}

\section{Study area}

The KNR is located in the southeast corner of the northeast Junggar Basin, Xinjiang (Fig. 1). It is dry and cold in winter and hot during the summer. Mean annual precipitation is $159 \mathrm{~mm}$, and mean annual evaporation $2090 \mathrm{~mm}$, which is characteristic of a typical temperate continental arid climate [2].

\section{Larvae collection}

Six Przewalski's horses and six Mongolian wild asses that died accidentally during the winter from 2010 to 2015 were preserved and necropsied. All Gasterophilus spp. larvae were collected from the digestive tracts.

A total number of 10 domestic horses (with no repeat samples) were randomly selected and treated once with ivermectin at the conventional dose of $0.2 \mathrm{mg} / \mathrm{kg}$ orally during the winter from 2013 to 2015 . Following ivermectin treatment, we collected Gasterophilus spp. larvae that were eliminated in all feces of each horse three times a day until there were no larvae for three consecutive days. The domestic horses had received no other anti-Gasterophilus drug treatment prior to the survey.

Larvae were stored in ethanol (100\%), washed with phosphate-buffered saline (PBS) buffer or saline solution $(0.9 \% \mathrm{NaCl})$, counted, and identified using the morphological keys in Zumpt [21].

\section{Statistical analysis}

The infestation prevalence, intensity, and abundance intensity were estimated according to Margolis and Schad [11].
Differences among the mean intensities of Gasterophilus spp. in the three equids were tested by the Kruskal-Wallis test. The statistical analysis and graphics were performed using SPSS version 20.0. A significant difference was assumed when $p \leq 0.05$.

\section{Results}

\section{Prevalence of Gasterophilus spp. larvae}

Gasterophilus spp. larvae were found within all 22 individuals of all three equid species. These included six species: G. haemorrhoidalis, G. inermis, G. intestinalis, G. nasalis, G. nigricornis, and G. pecorum.

Gasterophilus pecorum was the most common species $(100 \%)$ in the Przewalski's horse and the Mongolian wild ass. G. pecorum, G. nasalis, and G. nigricornis were found in every domestic horse (Table 1).

\section{Intensity infestation by Gasterophilus spp. larvae}

A total of 17,225 larvae were collected from the three equid species. There were significant differences in the intensities of Gasterophilus spp. $(p=0.000), G$. haemorrhoidalis $(p=0.047), G$. nasalis $(p=0.017)$, and $G$. pecorum $(p=0.000)$ in the three equids. The Przewalski's horse had the highest mean intensity of Gasterophilus spp. (1904) followed by the Mongolian wild ass (780) and the domestic horse (113) $(p=0.000)$ (Table 2).

\section{Abundance intensity of Gasterophilus spp. larvae}

$G$. pecorum was the most abundant species of Gasterophilus spp. in the three equids. The abundance intensity 
Table 1. Prevalence of Gasterophilus spp. larvae in three equids in Kalamaili Nature Reserve, China.

\begin{tabular}{|c|c|c|c|}
\hline \multirow[t]{3}{*}{ Gasterophilus spp. } & \multicolumn{3}{|c|}{ Equidae } \\
\hline & $\begin{array}{l}\text { Equus ferus } \\
\text { przewalskii }\end{array}$ & $\begin{array}{c}\text { Equus } \\
\text { hemionus }\end{array}$ & $\begin{array}{c}\text { Equus } \\
\text { caballus }\end{array}$ \\
\hline & $\begin{array}{c}\text { Positive } \\
\text { number (\%) }\end{array}$ & $\begin{array}{c}\text { Positive } \\
\text { number (\%) }\end{array}$ & $\begin{array}{c}\text { Positive } \\
\text { number (\%) }\end{array}$ \\
\hline G. pecorum & $6(100)$ & $6(100)$ & $10(100)$ \\
\hline G. nasalis & $3(50)$ & $4(66.67)$ & $10(100)$ \\
\hline G. nigricornis & $2(33.33)$ & $4(66.67)$ & $10(100)$ \\
\hline G. intestinalis & $2(33.33)$ & $1(16.67)$ & $7(70)$ \\
\hline G. haemorrhoidalis & $3(50)$ & $6(100)$ & $7(70)$ \\
\hline G. inermis & $0(0)$ & $1(16.67)$ & $3(30)$ \\
\hline Total & 6 & 6 & 10 \\
\hline
\end{tabular}

of G. pecorum was high, especially in the Przewalski's horse (1875.33) and the Mongolian wild ass (749.33). In the Mongolian wild ass, other species were $G$. nigricornis (17.83), G. haemorrhoidalis (9.67), G. nasalis (2.67), $G$. inermis (0.33), and $G$. intestinalis (0.17). In the domestic horse, the abundance intensity of $G$. nasalis (30.40) was higher than in the other two equids (Table 3 ).

\section{Discussion}

All three equids were infected with Gasterophilus spp. larvae. This may reflect a wide distribution of Gasterophilus spp. in KNR. The high prevalence of Gasterophilus spp. larvae $(100 \%)$ in the three equids is comparable to that reported for horses in Kazakhstan (100\%) [8]. In contrast, this prevalence is much higher than reported in Sanliurfa, Turkey (9.82\%) [7].

The mean intensities of Gasterophilus spp. larvae in Przewalski's horses (1904) and Mongolian wild asses (780) were higher than some reports from donkeys and horses in Asia [7, 12]. The lack of anti-parasitic treatment in wild equids in $\mathrm{KRN}$ may be the main reason for this situation, but it may also be due to the different climate and environment. However, the domestic horse had the lowest intensity of Gasterophilus spp. compared to the other two equids. This difference was partly attributed to the difference of habitats between the domestic horse and the other two equids. The summer pastures were mountain meadow with a lower temperature. The vegetation and water resources were more abundant than in KRN. These different environmental conditions may affect the activity of Gasterophilus spp. On the whole, our results indicate that the equids in KNR are severely affected by Gasterophilus spp. and the winter is not the main infection period for Gasterophilus spp. here.

$G$. pecorum was the most abundant species of Gasterophilus spp. in the three equids, which differs from studies in other regions of the world where it was reported that $G$. nasalis and $G$. intestinalis are the abundant species $[8,13$, $14,16]$. Our results suggest that $G$. pecorum is more adaptable to the local environment in KNR. G. pecorum was the only Gasterophilus spp. species that oviposits on grass [21]. The association with this unique behavior and the desert steppe ecosystem may help explain the situation.
Table 2. Intensity of Gasterophilus spp. larvae in three equids in Kalamaili Nature Reserve, China.

\begin{tabular}{lcccc}
\hline Gasterophilus spp. & \multicolumn{3}{c}{ Equidae } \\
\cline { 2 - 3 } & $\begin{array}{c}\text { Equus ferus } \\
\text { przewalskii }\end{array}$ & $\begin{array}{c}\text { Equus } \\
\text { hemionus }\end{array}$ & $\begin{array}{c}\text { Equus } \\
\text { caballus }\end{array}$ \\
\cline { 2 - 2 } \cline { 5 - 5 } G. pecorum & No. & No. & No. \\
G. nasalis & 11,252 & & 4493 & 621 \\
G. nigricornis & 91 & & 16 & 304 \\
G. intestinalis & 45 & & 107 & 126 \\
G. haemorrhoidalis & 6 & & 1 & 38 \\
G. inermis & 28 & & 58 & 30 \\
Total & 0 & & 2 & 7 \\
Mean \pm SD & 11,422 & & 4677 & 1126 \\
\hline
\end{tabular}

Table 3. Abundance intensity of Gasterophilus spp. larvae in three equids in Kalamaili Nature Reserve, China.

\begin{tabular}{lcccc}
\hline Gasterophilus spp. & \multicolumn{3}{c}{ Equidae } \\
\cline { 2 - 3 } & $\begin{array}{c}\text { Equus ferus } \\
\text { przewalskii }\end{array}$ & $\begin{array}{c}\text { Equus } \\
\text { hemionus }\end{array}$ & $\begin{array}{c}\text { Equus } \\
\text { caballus }\end{array}$ \\
\cline { 2 - 2 } \cline { 5 - 5 } & No. & No. & No. \\
\hline G. pecorum & 1875.33 & & 749.33 & 62.10 \\
G. nasalis & 15.17 & & 2.67 & 30.40 \\
G. nigricornis & 7.50 & & 17.83 & 12.60 \\
G. intestinalis & 1.00 & & 0.17 & 3.80 \\
G. haemorrhoidalis & 4.67 & & 9.67 & 3.00 \\
G. inermis & 0.00 & 0.33 & 0.70 \\
\hline
\end{tabular}

Water availability restricts the activity area of wild animals in a territory such as KNR which has low precipitation, high evaporation, and limited surface runoff. A previous study showed that the oviposition sites of $G$. pecorum are often near a water source [10]. This suggests that the water locations may be the important "epidemic" areas of G. pecorum. Przewalski's horses seem to drink daily [17]. For wild asses, it is often assumed that they can "regularly do without water" [1]. Frequent drinking at water sources may increase the risk of $G$. pecorum infection. Thus, the equids in arid desert grasslands have a higher intensity of Gasterophilus spp., and the intensity in Przewalski's horses is higher than in Mongolian wild asses.

Acknowledgements. This work was supported by the Fundamental Research Funds for the Central Universities (No. JC2015-04), the National Science Foundation of China (No. 30870463), and the Project of the Department for Wildlife and Forest Plants Protection, SFA of China (No. 2015-123).

\section{References}

1. Bahloul K, Pereladova OB, Soldatova N, Fisenko G, Sidorenko E, Sempere AJ. 2001. Social organisation and dispersion of introduced kulans (Equus hemionus kulan) and Przewalski horses (Equus przewalskii) in the Bukhara Reserve, Uzbekistan. Journal of Arid Environments, 47, 309-323. 
2. Chu HJ, Jiang ZG, Lan WX, Wang C, Tao YS, Jiang F. 2008. Dietary overlap among kulan Equus hemionus, goitered gazelle Gazella subgutturosa and livestock. Acta Zoologica Sinica, 54(6), 941-954 (in Chinese).

3. Chu HJ, Jiang ZG, Ge Y, Jiang F, Tao YS, Wang C. 2009. Population densities and number of khulan and goitred gazelle in Mt. Kalamaili Ungulate Nature Reserve. Biodiversity Science, 17(4), 414-422 (in Chinese).

4. Czosnek T. 1988. Gasterophilus infestation, the cause of death in a mare. Medycyna Weterynaryjna, 44, 346.

5. Doyle GM, John EH, Craig RR. 2003. Control of internal parasites of the horse. University of Tennessee, Institute of Agriculture, Website: http://trace.tennessee.edu/utk_agexani/ 34/. Accessed 19 December 2015.

6. Fan ZD. 1992. Index of common flies in China. Science Press: Beijing. p. 890-895 (in Chinese).

7. Gökcen A, Sevgili M, Altas MG, Camkerten I. 2008. Presence of Gasterophilus species in Arabian horses in Sanliurfa region. Türkiye Parazitoloji Dergisi, 32, 337-339.

8. Ibrayev B, Lider L, Bauer C. 2015. Gasterophilus spp. infections in horses from northern and central Kazakhstan. Veterinary Parasitology, 207(s1-2), 94-98.

9. Li K, Wu Z, Hu DF, Cao J, Wang C. 2007. A report on new causative agent (Gasterophilus spp.) of the myiasis of Przewalski's horse occurred in China. Acta Veterinaria et Zootechnica Sinica, 38(8), 837-840 (in Chinese).

10. Liu SH, Hu DF, Li K. 2014. Oviposition site selection by Gasterophilus pecorum (Diptera: Gasterophilidae) in its habitat in Kalamaili Nature Reserve, Xinjiang, China. Parasite, 22, 34.

11. Margolis L, Schad GA. 1982. The use of ecological terms in parasitology (report of an ad hoc committee of the American Society of Parasitologists). Journal of Parasitology, 68(1), 131-133.

12. Mukbel R, Torgerson PR, Abo-Shehada M. 2001. Seasonal variations in the abundance of Gasterophilus spp. larvae in donkeys in northern Jordan. Tropical Animal Health and Production, 33(6), 501-509.

13. Otranto D, Milillo P, Capelli G, Colwell DD. 2005. Species composition of Gasterophilus spp. (Diptera, Oestridae) causing equine gastric myiasis in southern Italy: parasite biodiversity and risks for extinction. Veterinary Parasitology, 133(1), 111-118.

14. Pandey VS, Ouhelli H, Verhulst A. 1992. Epidemiological observations on Gasterophilus intestinalis and Gasterophilus nasalis in donkeys from Morocco. Veterinary Parasitology, 41(3-4), 285-292.

15. Principato M. 1988. Classification of the main macroscopic lesions produced by larvae of Gasterophilus spp. (Diptera: Gasterophilidae) in free-ranging horses in Umbria. Cornell Veterinarian, 78(1), 43-52.

16. Principato M. 1989. Observation on the occurrence of five species of Gasterophilus intestinalis larvae in free-ranging horses in Umbria, Central Italy. Veterinary Parasitology, 31(2), 173-177.

17. Scheibe KM, Eichhorn K, Kalz B, Streich WJ, Scheibe A. 1998. Water consumption and watering behavior of przewalski horses (Equus ferus przewalskii) in a semireserve. Zoo Biology, 17, 181-192.

18. Wang MF 1998 Gasterophilus spp., in Flies in China (volume II), Science and Technology Press: Shenyang. p. 2207-2215 (in Chinese).

19. Yang JY, Zhang D, Hu DF, Chu HJ, Tao YS, Fan XZ, Li K. 2013. The injury caused by myiasis of Gasterophilus in horse. China Animal Husbandry and Veterinary Medicine, 40(5), 177-180 (in Chinese)

20. Yi Y, Song DR. 2008. Transitions: the prairie of Kazak herders and the stipulations. China Mapping, 1, 58-65 (in Chinese).

21. Zumpt F. 1965. Myiasis in man and animals in the old world: a textbook for physicians. Veterinarians and Zoologists: Butterworth, London.

Cite this article as: Huang $\mathrm{H}$, Zhang B, Chu H, Zhang D \& Li K: Gasterophilus (Diptera, Gasterophilidae) infestation of equids in the Kalamaili Nature Reserve, China. Parasite, 2016, 23, 36.

Reviews, articles and short notes may be submitted. Fields include, but are not limited to: general, medical and veterinary parasitology; morphology, including ultrastructure; parasite systematics, including entomology, acarology, helminthology and protistology, and molecular analyses; molecular biology and biochemistry; immunology of parasitic diseases; host-parasite relationships; ecology and life history of parasites; epidemiology; therapeutics; new diagnostic tools.

All papers in Parasite are published in English. Manuscripts should have a broad interest and must not have been published or submitted elsewhere. No limit is imposed on the length of manuscripts.

Parasite (open-access) continues Parasite (print and online editions, 1994-2012) and Annales de Parasitologie Humaine et Comparée (1923-1993) and is the official journal of the Société Française de Parasitologie. 